\title{
Developing A Framework To Investigate The Personal Financial Management Knowledge Of Individuals
}

\author{
FW Struwig \\ Department of Business Management, Nelson Mandela Metropolitan University \\ W Plaatjes \\ Department of Business Management, Walter Sisulu University
}

\begin{abstract}
This article focuses on the development of a framework for investigating the personal financial management knowledge of individuals. Content analysis is used to derive the components included in the personal financial management requirements framework. The framework developed includes six components, namely basic concepts in personal finances, management of personal finances, risk management, future planning, investing in financial resources and miscellaneous factors. A qualitative validation process revealed that the framework indeed covers what the average South African citizen is required to know about personal financial planning. The real test of this framework will be to use it in developing an instrument to test individuals' knowledge of personal financial management. This process of empirically testing the framework, using such an instrument, warrants a separate article.
\end{abstract}

JEL G29, M20

\section{1}

\section{Introduction}

Compared to a generation ago, South Africans now live in a world of great financial complexity and challenge. Changes in the financial services market and increases in the number of financial instruments available to families, coupled with intensive marketing campaigns within the financial services' sector, have made successful personal financial management much more difficult, and may even cause financial problems for families.

Money is an ancient and necessary human invention, but nowadays the explosion of information technology, forceful retail marketing techniques and the resourcefulness of criminals and fraudsters have all made the financial services sector a complex phenomenon. This sector in the twenty-first century is undergoing a major transformation, which has resulted in the need to educate consumers in personal finances.
Knowledge of personal financial management is required to improve an individual's or family's standard of living. Without personal finances education, personal financial problems arise, which can have detrimental effects on an individual's life at home and/or work. These problems include declining productivity, divorce in marriage and a poor self-image. Swart (2005) confirms that financial education is failing in South Africa.

To be able to educate individuals about personal financial management one has to consider the current knowledge of those individuals before a proper and useful training programme can be designed. In this article, a personal financial management requirements framework is developed to guide and enable the investigation of the personal financial management knowledge of individuals. To develop this framework, relevant literature is first evaluated, to determine what individuals have to know about personal financial management. 
Content analysis techniques are used to develop these components to include in the framework. Content analysis is part of qualitative research, and involves a systematic and intensive analysis of data, often sentence by sentence or phrase by phrase, with constant comparison (Strauss, 1993: 22). The focus of such analysis is not ordering a mass of data, but rather organising the many ideas that have emerged from analysis of the data. Thereafter experts in the field of personal financial management evaluate the proposed personal financial management requirements framework to validate it, by ensuring that it does indeed include all relevant issues.

\section{2}

\section{The concept of personal financial management}

Many studies (e.g. Chambliss, 1990; Gitman \& Joehnk, 1990; Whittaker, Heystek \& Metz, 1990; Toohey \& Toohey, 2000; Rosefsky, 2002) fail to define the concept "personal finances" or "personal financial management" adequately. Instead of using the concept "personal finances" or "personal financial management", for example, Gitman and Joehnk (1990) use "personal financial planning", but fail to define it properly.

Other studies use alternative terms. Godwin (1990: 103) for example uses the concept "family financial management", and defines it as "the planning, implementation, and evaluating by family members that [are] involved in the allocation of their current flow of income and their stock of wealth toward the end of meeting the family's implicit or explicit financial goals." Swart (2002) describes a similar conceptual framework for personal financial planning, though he does not define personal financial management. He sets out the management process of individual households as including the planning, organising, leading and controlling of the money matters of the household (Swart, 2002: 4).
For the purposes of this study, "personal finance(s)" or "personal financial management" will be defined as "a set of activities, including planning and decision making, organising, leading/implementing and controlling the allocation of income and the accumulation of wealth by an individual or family, with the aim of achieving implicit or explicit financial goals in an efficient and effective manner".

3

\section{The importance of personal financial management training and education}

Swart (2005) outlines the advantages of individuals' gaining financial expertise through training and education. These individuals, he says:

- have obtained one of the best life skills;

- possess entrepreneurial skills;

- $\quad$ are financially informed;

- have a financial advantage over others;

- can take personal responsibility for their financial future;

- have a better chance of financial success in business and in marriage; and

- should be financially independent at retirement.

These advantages make knowledge in financial management lucrative to individuals.

\section{4}

\section{A literature overview of the components included in personal financial management}

Table 1 outlines the components included in personal financial management as derived from literature using content analysis. 
Table 1

The components included in personal financial management

\begin{tabular}{|c|c|}
\hline Author & Component \\
\hline Garman and Forgue (1988) & $\begin{array}{l}\text { Planning personal finances } \\
\text { Managing personal finances } \\
\text { Managing expenditure } \\
\text { Protecting income and assets } \\
\text { Planning investments } \\
\text { Retirement planning } \\
\text { Estate planning }\end{array}$ \\
\hline Gitman and Joehnk (1990) & $\begin{array}{l}\text { Foundations of financial planning } \\
\text { Measuring financial standing } \\
\text { Insuring financial resources } \\
\text { Planning finances } \\
\text { Planning retirement and estate } \\
\text { Managing investments } \\
\text { Tax } \\
\text { Managing credit } \\
\text { Managing basic assets }\end{array}$ \\
\hline Whittaker, Haystek and Metz (1990) & $\begin{array}{l}\text { Managing finances and credit } \\
\text { Investing financial resources } \\
\text { Planning assets, insurance and retirement } \\
\text { Financial advice }\end{array}$ \\
\hline Kapoor, Dlabay and Hughes (1991) & $\begin{array}{l}\text { Planning personal finances } \\
\text { Managing personal finances } \\
\text { Making purchasing decisions } \\
\text { Insuring resources } \\
\text { Investing financial resources } \\
\text { Controlling the financial future }\end{array}$ \\
\hline Gordon-Fish (1994) & $\begin{array}{l}\text { Introduction to finances } \\
\text { Employment } \\
\text { Managing finances, banking services taxes and marriage } \\
\text { Investing financial resources } \\
\text { Assurance, retirement and wills } \\
\text { Health care }\end{array}$ \\
\hline Dewing (1995) & $\begin{array}{l}\text { Finances, insurance and tax } \\
\text { Accommodation } \\
\text { Job applications and interviews } \\
\text { Advice and assistance }\end{array}$ \\
\hline
\end{tabular}




\begin{tabular}{|c|c|}
\hline Author & Component \\
\hline Rosefsky (2002) & $\begin{array}{l}\text { Basic requirements } \\
\text { Accommodation } \\
\text { Investing financial resources } \\
\text { Providing for needs } \\
\text { Protecting resources } \\
\text { Financing }\end{array}$ \\
\hline Swart (2002) & $\begin{array}{l}\text { Career planning } \\
\text { Income tax planning } \\
\text { Estate planning } \\
\text { Investment planning } \\
\text { Protection planning } \\
\text { Credit planning } \\
\text { Health care planning } \\
\text { Retirement planning } \\
\text { Emigration planning }\end{array}$ \\
\hline $\begin{array}{l}\text { Ernst \& Young, Nissenbaum, Raasch } \\
\text { and Ratner (2004) }\end{array}$ & $\begin{array}{l}\text { Financial planning } \\
\text { Accommodation } \\
\text { Investing financial resources } \\
\text { Retirement planning } \\
\text { Health care } \\
\text { Marriage/divorce } \\
\text { Protecting resources }\end{array}$ \\
\hline Woerheide (2004) & $\begin{array}{l}\text { Financial planning } \\
\text { Accommodation } \\
\text { Protecting resources } \\
\text { Investing financial resources } \\
\text { Retirement planning } \\
\text { Estate planning }\end{array}$ \\
\hline
\end{tabular}

To derive the components outlined in Table 1, an intensive study of the relevant literature was conducted. Many more frameworks than those listed in Table 1 were investigated, but some frameworks were excluded because the core categories were saturated and were linked in numerous ways with the proposed categories. The efforts of researchers such as Joo (1998) and Kim (2000) were adapted for South African conditions to ensure their components are also covered in the framework.

The components included by the various authors as outlined in Table 1 can be analysed, and some of them proposed for inclusion in the framework for personal financial management requirements. These components were derived using content analysis. A text, which can be written, spoken or visual, has content, in other words the messages it contains in the form of words, meanings, symbols and themes. Content analysis is the gathering and analysis of textual content, and can include quantitative and qualitative evaluations of text. The central idea in content analysis is that the many words of the text are classified into relatively fewer content categories (Struwig \& Stead, 2001). 
5

Proposed components for inclusion in the personal financial management requirements framework

\subsection{Component 1: Basic concepts in personal finances}

Basic concepts in personal finances include the personal financial management process, the economic environment and various aspects relating to earning an income.

\section{(a) Personal financial management process}

To understand personal financial management, it is important to consider the personal financial management process. This process involves setting personal financial goals and implementing strategies to achieve them (Kapoor et al., 1991; Whittaker et al., 1990). A personal financial plan includes the "financial" goals, a net worth statement, an income and expense record, an insurance and assurance plan, a saving and investing plan and a budget (McCorkle, et al., 2002).

\section{(b) Economic environment}

The micro- and macro-economic environments have to be explained in order to understand financial terminologies and opportunities. The micro environment includes economic problems (resources, needs and wants), opportunity cost, etc. The macro environment consists of the economy as a whole, monetary policy (including interest rates and money supply), inflation (including the basic time value of money), economic indications, balance of payments, fiscal policy, exchange rates and financial institutions (including range of services banks offer and the Reserve Bank) (Gordon-Fish, 1994; Rosefsky, 2002; Swart, 2002).

\section{(c) Income}

The income of individuals is influenced by the availability, standard, quality and content of the education they have received. Education influences not only the enjoyment of life but also the attainment of a "job", which here means a satisfying career and a good income (Sylvia \& Horne, 1992). A job includes the role of employment in an individual's life, factors in choice of work, the quest for a job, the curriculum vitae, the interview process and ways to negotiate the best remuneration package. Various important factors in discussing a "job" are items to be aware of when starting new employment or changing careers, strategies amidst organisational change, taking advantage of fringe benefits and tax breaks, being unemployed and work and income legislation (Gordon-Fish, 1994; Dewing, 1995; Rosefsky, 2002; Swart, 2002).

\subsection{Component 2: Management of personal finances}

The management of personal finances includes the budgeting process and various aspects of credit, savings and income tax planning.

\section{(a) Budgeting process}

Budgeting serves as a guide to help people live within their income. The budgeting process includes drawing up and operating a budget (which includes tracking and reconciling the budget). Ways of overcoming budget shortfalls and various available personal financial software packages should also be examined (Chambliss, 1990; Gitman \& Joehnk, 1990; Theys, 1993; McCorkle et al., 2002; SAQA, 2002; Swart, 2002).

Important aspects of expenditure are firstly, avoiding the trap of failing to plan for all expenses and secondly, identifying how one wastes money. Expenditure may include financial expenditures and maintenance issues related to maintaining assets. Planning for major expenditure can de done using the life cycle planning method (Garman \& Forgue, 1988; Toohey \& Toohey, 2000; SAQA, 2002).

Important aspects of record keeping are firstly, organising personal financial records, secondly, determining one's current financial position and thirdly, using a cash flow statement to assist with financial planning (Kapoor et al., 1991; Sylvia \& Horne, 1992). 


\section{(b) Credit}

Credit appears to be the major cause of financial downfall for many individuals. Important factors to understand include the various forms of debt, the concept of delay and why individuals use (Burger, 1990; Chambliss, 1990; Theys, 1993; Dewing, 1995):

- Various forms of debt: These include the different types of credit cards, revolving credit, basic features of consumer loans and instalment payments (Gitman \& Joehnk, 1990; Liberman \& Lavine, 1994; McCorkle, et al., 2002).

- Applying for credit: This process includes understanding credit requirements; evaluating credit applications by a lender i.e. credit worthiness; answering questions such as, 'Should I co-sign a loan for a friend or a relative?'; reviewing the do's and don'ts of applying for a loan; and knowing the various sources of credit (Chambliss, 1990: 59-87; Gitman \& Joehnk, 1990: 219-251; Kapoor et al., 1991; Rosefsky, 2002; Swart, 2002)

- Credit record: An individual's credit record consists of credit information maintained in reports at the credit bureau. Maintaining a credit rating includes checking and understanding your credit report and correcting errors (Whittaker et al., 1990; Kapoor et al., 1991; Liberman \& Lavine, 1994; McCorkle et al., 2002; Swart, 2002).

- Credit management: This includes managing credit cards and protecting credit users; deciding how much open-ended credit to use; choosing whether to borrow or wait and pay cash; planning credit use; and understanding credit agreement contracts (Garman \& Forgue, 1988).

- The cost of credit: Questions to understand include how the cost of credit is calculated, how much credit one can afford to use and the best way to compare different credit plans. Leasing, borrowing-to-buy and rent-to-own options have different contract terms and costs. The various forms of credit, including retail charge cards, bank credit cards and open lines of credit, should included in the requirements framework (Kapoor et al., 1991; McCorkle et al., 2002; Rosefsky, 2002).

- Excessive debt: This includes indicators and consequences of excessive debt, credit card problems, credit matters to beware of and where to seek assistance in case of credit problems. Individuals with excessive debt have a number of options including re-negotiating a repayment schedule or selling assets (Garman \& Forgue, 1988; Kapoor et al., 1991; Van der Watt, 1991; Liberman \& Lavine, 1994; Smith, 1994; McCorkle et al., 2002).

- Bankruptcy: Issues to discuss include the protection of assets from creditors, the declaration of bankruptcy, various ways of getting credit after bankruptcy and the three types of bankruptcy (Chambliss, 1990; Liberman \& Lavine, 1994).

- Credit and the law: Laws and regulations exist to protect consumers from shady lenders. The following issues are important: current laws that protect the rights of borrowers; legal expiry date of debts; different types of debt; classification of debts; ranking or prioritising of debts; offering a settlement; voluntary distribution; administration orders and the sequestration of estates (Kapoor et al., 1991; Theys, 1993; McCorkle et al., 2002).

\section{(c) Savings}

Individuals should understand the various concepts involved in savings, including reasons for saving, the importance of saving, setting saving targets, the saving process, places to save, available types of savings instrument, advice for becoming a disciplined saver, special purpose accounts, comparison of savings accounts and savings plans and saving versus investing (Chambliss, 1990; Gitman \& Joehnk, 1990; Whittaker et al., 1990; Kapoor et al., 1991; McCorkle et al., 2002). A saving mindset must be cultivated, and individuals understand such matters as why spending less should be easier than saving more, and how to apply savings strategies for purchasing large appliances (Toohey \& Toohey, 2000: 13-58). 


\section{(d) Income tax planning}

Individuals should know about the basics of income tax planning, including how to determine their taxation liability and the different types of taxes payable. The basics of income tax planning include the definition of tax, the principles of income tax, the Income Tax Act, the Margo Report, the importance of keeping tax records, managing taxes, the various ways to pay tax and places to get help; these must included in the requirements framework (Jordaan, 1989; Gitman \& Joehnk, 1990; Whittaker et al, 1990; Kapoor et al., 1991; Gordon-Fish, 1994; Dewing, 1995).

Determining one's taxation liability involves understanding the tax year and tax rates, methods of avoiding tax, tax-cutting strategies and tax evasion versus tax avoidance, as well as how to document income and expenses, how to complete a tax return, and what to do if one is audited (Garman \& Forgue, 1988; Gitman \& Joehnk, 1990; Kapoor et al., 1991; Rosefsky, 2002).

The different kinds of tax include estate duty and capital transfer tax, transfer duty, stamp duty, the tax implications of retirement and its impact on a will and the standard income tax on employees (SITE) (Garman \& Forgue, 1988: 99-229; Jordaan, 1989: 181-200; Gitman \& Joehnk, 1990: 98-128; Sylvia \& Horne, 1992: 33-83; Swart, 2002: 69-75).

\subsection{Component 3: Risk management}

Risk management includes an overview of insurance and assurance, and what medical and hospital options are available.

\section{(a) Insurance overview}

An insurance overview should contain a definition of insurance, the concept of risk management, the difference between insurance (short-term) and assurance (long-term), the process of applying for insurance, risk assessment, lodging a claim, the regulation of insurance and selecting an insurance agent (Fowler, 1987; Garman \& Forgue, 1988; Whittaker et al., 1990; Gitman \& Joehnk, 1990; Kapoor et al., 1991; Sylvia \& Horne, 1992; Dewing, 1995).

Various kinds of insurance are available, including fire, theft, all risk, engineering, glass, marine and transport, first loss, aviation, motor vehicle, liability, credit, surety or fidelity, loss of profits and legal expenses. Other types of insurance include personal accident and sickness, endowment "insurance," and the classification of pure risks and business insurance (Fowler, 1987; Jordaan, 1989; Burger, 1990; Gitman \& Joehnk, 1990; Sylvia \& Horne, 1992; Dewing, 1995).

A description of group insurance should include the various types, continuation options, contributions to personal security programmes, group disablement and group life insurance (Fowler, 1987).

Individuals also need to understand policy wording and concepts such as "utmost good faith", indemnity (not for profit), substitution rights of insurer, the average clause, insurable interest, reinsurance and actuaries (Fowler, 1987; Gitman \& Joehnk, 1990).

\section{(b) Assurance overview}

An overview of assurance should contain a definition of assurance, the reasons for life assurance, the difference between a policy owner and a policy holder, the basic elements of an assurance policy and drawing up a personal prosperity plan. Aspects of assurance coverage include assurance policies with profits and nonprofit policies, the "basic building blocks" of an assurance policy, disablement insurance, how premiums are determined, variable or linked policy benefits, profit sharing policy benefits, capital bonuses policy benefits, how inflation affects policy values, lodging a claim and the payment of benefits. Also important are the life assurance requirements over one's lifetime and the purchasing of life assurance (Fowler, 1987; Garman \& Forgue, 1988; Sylvia \& Horne, 1992). 
Various types of assurance policy packages exist, such as: whole life assurance, endowment, annuities, certain immediate and deferred, retirement annuity, terms, level or decreasing, guaranteed insurability, accident benefits, disability, dreaded disease, premium waivers, income protection, joint life insurance, key man insurance, deferred compensation and partnership insurance (Fowler, 1987; Sylvia \& Horne, 1992). These need to be adequately understood.

The concepts and wording of the assurance policy such as the growth factor, brokers and surrendering a policy must be understood (Fowler, 1987; Gitman \& Joehnk, 1990; Sylvia \& Horne, 1992).

\section{(c) Medical aid and hospital plans}

Important aspects of health cover/medical aids include the nature and importance of medical costs, factors that affect health, providing for medical expenses, the types of health insurance cover, determining health insurance requirements, the health insurance policy, the principles of health insurance, the cost of medical care and loss of income and the Life Office Association (Fowler, 1987; Garman \& Forgue, 1988; Kapoor et al., 1991; Sylvia \& Horne, 1992; Gordon-Fish, 1994).

Understanding the health-care system includes knowing about the medical services offered by the various types of hospitals and clinics, the ambulance services, the hospice and various other ways to stay healthy (Sylvia \& Horne, 1992; Gordon-Fish, 1994). Group schemes for medical aid and medical benefits are also important (Fowler, 1987).

\subsection{Component 4: Investing in financial resources}

Investing in financial resources requires knowing about various aspects relating to accommodation, vehicles and investment planning.

\section{(a) Accommodation}

Rental accommodation involves aspects such as available housing alternatives, housing space, life values and goals, the pros and cons of buying and renting, shopping for rentals, ways to negotiate a lease agreement, the lease and some important clauses (for example month-to-month tenancy), combinations of leasing and buying, rental laws, terminating a lease and helpful advice regarding leasing (Garman \& Forgue, 1988; Kapoor et al., 1991; Sylvia \& Horne, 1992; Gordon-Fish, 1994; Liberman \& Lavine, 1994; Rosefsky, 2002).

Pre-purchase factors for consideration when buying a home include the dilemma in timing the purchase of the dwelling at the right price, factors that affect the price of a home, making the purchase, financing a home, calculating affordability (including the government subsidy), the various aspects of a mortgage bond and an overview of timeshare. There are various types of home ownership, namely sectional title, share block, cluster housing, plot and plan schemes and self-help schemes (Garman \& Forgue, 1988; Sylvia \& Horne, 1992; Kapoor et al., 1991; Gordon-Fish, 1994; Rosefsky, 2002).

The cost of purchasing a home includes 'hidden' costs arising from property insurance, property taxes, utilities, maintenance and repairs and the laws regulating housing. An overview regarding home improvements and extensions is also an important factor in the framework (Garman \& Forgue, 1988; Sylvia \& Horne, 1992; Rosefsky, 2002).

Preparing a home for sale includes aspects such as setting a price, options in selling a house, contracting an estate agent versus selling it yourself, tax implications, documenting the sale, when to sell a house, the transfer, possession of the property, the concept of 'voetstoots' and taking the moving expenses into account (Garman \& Forgue, 1988; Sylvia \& Horne, 1992; Gordon-Fish, 1994; Rosefsky, 2002).

\section{(b) Vehicles}

An overview of buying new and used vehicles includes setting the criteria for choosing a vehicle, checking the condition of the vehicle and the roadworthy certificate, transferring ownership, examining the cost of optional extras, 
exploring trade-in, warranties and guarantees. Various financing options are included, such as, where to get a vehicle loan, simple interest on a vehicle loan, the deposit, terms of the loan, tax-free borrowing for a vehicle, variable-rate vehicle loan, leasing versus purchasing of a vehicle, negotiating the best price for a vehicle, different ways to save money and repossessing a vehicle (Garman \& Forgue, 1988; Kapoor et al., 1991; Sylvia \& Horne, 1992; Liberman \& Lavine, 1994).

\section{(c) Investment planning}

An investment planning strategy should include setting investment goals and an investment philosophy, choosing alternative investments, exploring factors affecting the rate of return, achieving investment goals, choosing fixed asset investments and using computer-based investment analysis (Garman \& Forgue, 1988; Chambliss, 1990; Gitman \& Joehnk, 1990; Toohey \& Toohey, 2000; Rosefsky, 2002).

\subsection{Component 5: Planning the future}

Planning the future consists of estate and retirement planning and planning a will.

\section{(a) Estate and retirement planning}

The main activities of estate planning should include meeting retirement goals, deciding when to start planning for retirement, and understanding estate planning, limited rights, the jargon of estate planning, what an estate plan should accomplish and how estate taxes work. The most essential part of retirement planning is providing for a surviving spouse and other heirs (including minors), planning for continuity, massing a will, ensuring substitution, appointing executors and administrating an estate. Additional factors to consider are inflation, financial planning for retirement, investment strategies for retirement, the role of a trust in estate planning, the types of retirement accommodation that are available, tax-sheltered retirement benefits and the main sources of retirement income (Garman \& Forgue, 1988; Gitman \& Joehnk, 1990; Kapoor et al., 1991; Toohey \& Toohey, 2000; Rosefsky, 2002).

\section{(b) Planning a will}

Wills and other devices for passing on accumulated wealth, including trusts, donation tax and transfers at death, are also important in the framework (Garman \& Forgue, 1988; Gitman \& Joehnk, 1990; Rosefsky, 2002).

\subsection{Component 6: Miscellaneous}

The miscellaneous component is the most dynamic of all the components, as any subject of a current or common nature that affects individuals financially may be included. This section includes finances in marriage and parenting, advice and assistance 'persons' and consumer complaints.

\section{(a) Finances in marriage and parenting}

The term marriage includes common-law marriage. The section includes finances in marriage, finance in parenting, where to find help in times of crisis, registering a birth, teaching children "at the dinner table", spending money on children, financial discipline and children, setting high expectations for children without driving them insane and getting through the "problem" years without losing money or one's mind (Sylvia \& Horne, 1992; Toohey \& Toohey, 2000).

\section{(b) Advice and assistance}

Advice and assistance includes legal aid organisations, the Consumer Council, family planning, child welfare, substance abuse organisations, physical abuse organisations and emotional/psychological counselling organisations (Dewing, 1995).

\section{(c) Consumer complaints}

Consumer complaint procedures should be clearly understood. A complaint should be directed to the organisation concerned through its progressive tiers of management. If this approach fails formal complaints can be lodged with quasigovernmental/community agencies that can assist consumers in resolving problems with goods and services (McCorkle, et al., 2002). 
Table 2 outlines the components contained in the proposed financial management requirements framework.

Table 2

Proposed personal financial management requirements framework

\begin{tabular}{|c|c|c|}
\hline $\begin{array}{l}\text { Component } 1 \text { : Basic concepts in } \\
\text { personal finances }\end{array}$ & $\begin{array}{l}\text { Component 2: Management of } \\
\text { personal finances }\end{array}$ & Component 3: Risk Management \\
\hline $\begin{array}{l}\text { - The process } \\
\text { - The economic environment } \\
\text { - Income from the viewpoint of } \\
\text { education and the job }\end{array}$ & $\begin{array}{l}\text { - } \text { Budgeting: } \\
\text { - Credit } \\
\text { - Savings } \\
\text { - Income tax planning }\end{array}$ & $\begin{array}{l}\text { - Insurance } \\
\text { - Assurance } \\
\text { - Medical aids and hospital } \\
\text { plans }\end{array}$ \\
\hline $\begin{array}{l}\text { Component 4: Investing } \\
\text { financial resources }\end{array}$ & $\begin{array}{l}\text { Component 5: Planning the } \\
\text { future }\end{array}$ & Component 6: Miscellaneous \\
\hline $\begin{array}{ll}\text { - } & \text { Accommodation } \\
\text { - } & \text { Vehicles } \\
\text { - } & \text { Investment planning }\end{array}$ & $\begin{array}{l}\text { - } \\
\text { - } \quad \text { Planning a will }\end{array}$ & 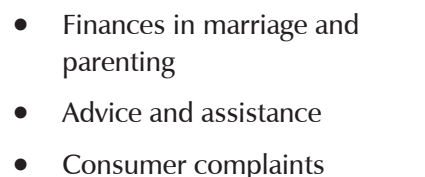 \\
\hline
\end{tabular}

The components outlined in Table 2 constitute a framework that can be used to evaluate the personal financial management knowledge of individuals. Individuals are expected to have knowledge of these components to be able to manage their personal finances.

\section{6}

\section{Evaluation by personal financial management experts}

\subsection{The sample}

A sample of twenty personal financial management experts in South Africa was invited to evaluate the proposed personal financial management requirements framework (Table 2 ). The names of these personal financial management experts were sourced from various websites, telephone directories and Telkom's number enquiry call-centre. Of the twenty experts invited, nine were willing to evaluate the framework. Three of the nine personal financial management experts are well known financial experts in South Africa. Of the financial experts, 67 per cent are from the Gauteng area and 11 per cent each from Western Cape, Eastern Cape and KwaZulu Natal.

\subsection{How the evaluation was performed}

The sample of twenty personal financial management experts were each e-mailed or faxed an invitation to participate, the personal financial management requirements framework (Table 2) and a questionnaire. The purpose of the invitation was to explain the objective of the research and its expected outcomes, to assure prospective participants of confidentiality and to indicate the researcher's contact details. The questionnaire indicated the task requirement, the time involved in the evaluation process, the due dates and the questions requiring answers. The completed (signed and dated) invitations were returned to the researcher by fax or e-mail, who then sent an explanation of the framework to the expert for complete evaluation. As mentioned above, nine completed invitations were returned.

\subsection{The questionnaire}

The questionnaire consisted of four openended questions that required an analysis of the framework and comments on the components. The intention of the questionnaire was to obtain qualitative data and an in-depth analysis of the content. 


\subsection{Reliability and validity of the study}

In content analysis, the method used to develop the personal financial management requirements model, information is broken down conceptually and put back together in new ways (De Vos, Strydom, Fouch \& Delport, 2002). There are various ways of confirming or validating qualitative data. One such method, namely theoretical validity, requires that there be common agreement among the researcher and the participants about the concepts or theory used to explore the phenomena being investigated (Struwig \& Stead 2001). The intention of the qualitative study was thus to ensure that the personal financial management requirements model developed by the researcher does indeed contain relevant and necessary concepts. In qualitative research, reliability is also synonymous with consistency. Proper text analyses were done to ensure that the results were reliable.

\subsection{The findings of the personal financial management experts}

\section{(a) The respondents}

All the respondents are certified financial planners and most of them have post-graduate qualifications. With the exception of one respondent, who has eight years' experience, the respondents all have more than ten years experience in the financial planning business. Two thirds of the respondents are male and one third female.

\section{(b) Analysis of the experts' findings}

The consensus of the personal financial management experts who responded is that the requirements framework indeed covers what the average South African citizen should know regarding personal financial management. The main criticism involves the depth of the framework content. Two of the respondents stated that the framework may include too many aspects and in fact includes more than what the average individual should know about personal financial management.

Themes that emerged from this analysis include the following:
- personal finance is a skill that is learnt by doing rather than by theoretical learning;

- money is an emotional subject;

- your financial plan should be driven by your lifestyle goals;

- $\quad$ each individual should have a life plan;

- each individual has a money personality that influences his or her behaviour; and

- individuals may not see insurance and investments as separate.

\section{7}

\section{Conclusions and recommendations}

The personal financial management requirements framework developed can be used in various ways. Firstly, it can be used to investigate and analyse the personal financial management knowledge of individuals to ensure proper training and education in specific areas. Secondly, it can be used as a theoretical base to develop an instrument to investigate the personal financial knowledge of individuals.

The proposed personal financial requirements framework includes six cardinal components, namely: 1. Basic concepts in personal finances; 2. Management of personal finances; 3. Risk management; 4. Future planning; 5. Investing in financial resources; and 6. Miscellaneous.

This framework was examined and evaluated by leading personal finances experts. These experts agreed that the personal financial requirements framework indeed covers what the average South African citizen is required to know about personal finance. The themes that emerged in analysing the responses of the personal financial management experts provide valuable guidelines for developing an instrument to investigate the personal financial management knowledge of individuals. Suggestions include the following:

- practical exercises will be necessary as personal finances is a skill that is developed by doing;

- lifestyle planning and management are important; and

- $\quad$ proper understanding of what investments are will be required. 
The real test of this framework will be utilising it for the development of an instrument to test individuals' knowledge of personal financial management. The process of testing the framework, however, warrants a separate article.

\section{References}

1 BURGER, M. (1990) Financial Matters, Out of Africa: Pretoria.

2 CHAMBLISS, H.D. (1990) The Bank of America Guide to Making the Most of your Money, Dow Jones: Homewood, Illinois.

3 DE VOS, A.S.; STRYDOM, H.; FOUCHE, C.B. \& DELPORT, C.S.L. (2002) Research at Grass Roots for the Social Sciences and Human Service Professions, Van Schaik: Pretoria.

4 DEWING, L. (1995) Things You Need to Know, but Nobody Told You, Don Nelson: Cape Town.

5 ERNST \& YOUNG, L.L.P.; NISSENBAUM, M.; RAASCH, B.J. \& RATNER, C.L. (2004) Ernst \& Young's Personal Financial Planning Guide, ( $5^{\text {th }}$ ed.), John Wiley: New York.

6 FOWLER, D. (1987) Financial Security in South Africa, Sigma Press: Pretoria.

7 GARMAN, E.T. \& FORGUE, R.E. (1988) Personal Finance (2nd ed.) Houghton Mifflin: Boston.

8 GITMAN, L.J. \& JOEHNK, M.D. (1990) Personal Financial Planning ( $5^{\text {th }}$ ed.) The Dryden Press: Orlando.

9 GODWIN, D.D. (1990) "Family financial management," Family Relations, 39(2): 221-228. http://globalvgw11.global.epnet.com/ehost.asp? (Accessed 27 January 2004).

10 GORDON-FISH, Z. (1994) Cosmopolitan Money Power, Metz Press: Cape Town.

11 JOO, S. (1998) "Personal financial wellness and worker job productivity”, Unpublished doctoral dissertation, Virginia Polytechnic Institute and State University: Blacksburg.

12 KAPOOR, J.R.; DLABAY, L.R. \& HUGHES, R.J. (1991) Personal Finance ( $2^{\text {nd }}$ ed.) Irwin: Boston.

13 KIM, J. (2000) "The effects of workplace financial education on personal finances and work outcomes", Unpublished doctoral dissertation, Virginia Polytechnic Institute and State University: Blacksburg.

14 LIBERMAN, G. \& LAVINE, A. (1994) ICFP Personal Wealth Building Guides: Improving Your Credit and Reducing Your Debt, John Wiley:

New York.

15 MCCORKLE, S.; BANNISTER, R.; BROWN, N.; CLOW, J.; HECKMAN, P. \& O'NEILL, B. (2002) "Jumpstart: Financial smarts for students." National Endowment for Financial Education, http://jumpstartcoalition.org (Accessed 27 June 2004).

16 ROSEFSKY, R.S. (2002) Personal Finance, ( $8^{\text {th }}$ ed.) John Wiley: New York.

17 SAQA (South African Qualifications Authority). (2002) Apply Principles of Financial Well-being, http://www.saqa.org/sgb/lifeskills/abet04-01.pdf (Accessed 22 June 2004).

18 SMITH, S.S. (1994) Exploding the Doomsday Money Myths, Thomas Nelson Publishers: Nashville, Tennessee.

19 STRAUSS, A.L. (1993) Qualitative Analysis for Social Scientists: Cambridge University Press, Cambridge.

20 STRUWIG, F.W. \& STEAD, G.B. (2001) Planning, Designing and Reporting Research, Pearson Education: Cape Town.

21 SWART, N. (2002) Personal Financial Management ( $2^{\text {nd }}$ ed.) Juta: Cape Town.

22 SWART, N. (2005) "Why financial literacy is a complete failure," Management Today, pp 48-50.

23 SYlVIA, V. \& HORNE, L.G. (eds.) (1992) The How To?, Sylvia Publishers: Johannesburg.

24 THEYS, J. (1993) Coping with Debt, Southern Book Publishers: Pretoria.

25 TOOHEY, B. \& TOOHEY, M. (2000) The Average Family's Guide to Financial Freedom, John Wiley \& Sons.

26 VAN DER WATT, T. (1991) The Beginner's Money Manual, Human \& Rousseau: Cape Town.

27 WHITTAKER, N.; HEYSTEK, M. \& METZ, R. (1990) Nedbank's Making Money Made Simple, Unique Press: Cape Town.

28 WOERHEIDE, W. (2004) Core Concepts of Personal Finance, John Wiley: New York. 